\title{
PENGARUH PRAKTIK PENGALAMAN LAPANGAN TERHADAP KINERJA MAHASISWA CALON GURU
}

\author{
Pungky Hapsari \\ Purweni Widhianningrum \\ IKIP PGRI Madiun \\ weni.widhi@gmail.com
}

\begin{abstract}
This study aimed to examine pedagogic competence, professional competence, social competence, and personal competence on the student teachers performance. The population in this study were all students of Accounting Departement of IKIP PGRI Madiun class of 2008 and 2009 which implement Practice Experience (PPL) in Madiun with the number of 204 students. The sample obtained based on purposive sampling and 150 students as respondents. Data analysis method used multiple regression analysis. The results showed that social competence and personal competence have significant and positive effect on the performance of student teachers. While the pedagogical competence and professional competence has no significant effect on the performance of student teachers.
\end{abstract}

Keywords: pedagogic competence, professional competence, social competence, personal competence, and performance.

\begin{abstract}
Abstrak: Penelitian ini bertujuan untuk menguji kompetensi pedagogik, kompetensi profesional, kompetensi sosial, dan kompetensi kepribadian terhadap kinerja mahasiswa calon guru. Populasi dalam penelitian ini adalah seluruh mahasiswa Program Studi Pendidikan Akuntansi IKIP PGRI Madiun angkatan 2008 dan 2009 yang melaksanakan Praktik Pengalaman Lapangan (PPL) di Madiun dengan jumlah 204 mahasiswa. Pengambilan sampel dilakukan dengan metode purposive sampling sehingga total sampel yang digunakan sejumlah 150 responden, sedangkan pengumpulan data dilakukan dengan wawancara dan kuesioner. Metode analisis data yang digunakan adalah regresi berganda. Hasil penelitian menunjukkan bahwa kompetensi sosial dan kompetensi kepribadian berpengaruh positif dan signifikan terhadap kinerja mahasiswa calon guru Program Studi Pendidikan Akuntansi IKIP PGRI Madiun dalam melaksanakan Praktik Pengalaman Lapangan. Sementara itu, kompetensi pedagogik dan kompetensi profesional tidak berpengaruh signifikan terhadap kinerja mahasiswa calon guru.
\end{abstract}

Kata Kunci: kompetensi pedagogik, kompetensi profesional, kompetensi sosial, kompetensi kepribadian, dan kinerja.

Guru merupakan komponen yang paling berpengaruh terhadap terciptanya proses dan hasil pendidikan yang berkualitas. Perbaikan kualitas pendidikan harus berpangkal dari guru dan berujung pada guru. Upaya perbaikan untuk meningkatkan kualitas pendidikan tidak akan memberikan sumbangan apapun tanpa didukung oleh guru yang profesional dan berkualitas (Mulyasa, 2009:5). 
Pendidikan adalah penentu sebuah bangsa menjadi maju, berkembang, dan berkualitas. Indikator kemajuan sebuah bangsa ditentukan oleh maju tidaknya pendidikan bangsa tersebut (Barizi dan Idris, 2010). Lembaga Pendidikan Tenaga Kependidikan (LPTK), sebagai suatu lembaga pendidikan guru tingkat universitas, memiliki peranan penting dalam mempersiapkan dan menyediakan calon-calon guru yang memiliki kompetensi profesional yang baik (Hamalik, 2004:49). Kompetensi guru diperlukan dalam rangka mengembangkan dan mendemonstrasikan perilaku pendidikan, bukan sekedar mempelajari keterampilan-keterampilan mengajar tertentu, tetapi merupakan penggabungan dan pengaplikasian suatu keterampilan dan pengetahuan yang saling bertautan dalam bentuk perilaku nyata (Mulyasa, 2009:31).

Peraturan Pemerintah (PP) Nomor 19 tahun 2005 tentang Standar Nasional, menyebutkan empat (4) kompetensi yang harus dimiliki oleh seorang guru, yaitu kompetensi pedagogik, kompetensi kepribadian, kompetensi profesional, dan kompetensi sosial. Kompetensi pedagogik adalah kemampuan mengelola pembelajaran peserta didik yang meliputi pemahaman terhadap peserta didik, perancangan dan pelaksanaan pembelajaran, pengevaluasian hasil belajar, serta pengembangan peserta didik untuk mengaktualisasikan berbagai potensi yang dimilikinya. Kompetensi kepribadian adalah kemampuan kepribadian yang mantap, stabil, dewasa, arif, berwibawa, berakhlak mulia, dan menjadi teladan bagi peserta didik. Kompetensi professional adalah kemampuan penguasaan materi pembelajaran secara luas dan dalam yang memungkinkannya membimbing peserta didik memenuhi standar kompetensi yang ditetapkan dalam Standar Nasional Pendidikan. Kompetensi sosial adalah kemampuan pendidik sebagai bagian dari masyarakat untuk berkomunikasi dan bergaul secara efektif dengan peserta didik, sesama pendidik, tenaga kependidikan, orangtua/wali peserta didik, serta masyarakat sekitar.

Praktik Pengalaman Lapangan merupakan serangkaian kegiatan yang diprogramkan bagi siswa calon guru yang meliputi latihan mengajar maupun latihan di luar mengajar sebagai ajang untuk membentuk dan membina kompetensi-kompetensi profesional yang disyaratkan oleh pekerjaan guru atau kependidikan yang lain. Sasaran yang ingin dicapai adalah pribadi calon pendidik yang memiliki seperangkat pengetahuan, keterampilan, nilai, sikap, pola tingkah laku yang diperlukan bagi profesinya, serta cakap dan tepat menggunakannya di dalam penyelenggaraan 
pendidikan dan pengajaran, baik di sekolah maupun di luar sekolah (Hamalik, 2004:171).

Pelaksanaan PPL pada dasarnya bertujuan memperoleh kompetensi yang relevan dengan tugas guru yang berkaitan dengan pembelajaran, pelatihan, dan pembimbingan. Kompetensi ini perlu dimiliki oleh mahasiswa praktikan untuk menyiapkan diri dalam rangka mengantisipasi apa yang tersirat dalam UU Nomor 20 tahun 2003. UU Nomor 20 tahun 2003 menyatakan bahwa pendidikan adalah usaha sadar dan terencana untuk mewujudkan suasana belajar dan proses pembelajaran agar peserta didik secara aktif mengembangkan potensi diri guna memiliki kekuatan spiritual keagamaan, pengendalian diri, kepribadian, kecerdasan, akhlak mulia, serta keterampilan yang diperlukan dirinya, masyarakat, bangsa dan negara.

Kinerja mengajar bagi calon guru merupakan titik kulminasi perkuliahan yang dipengaruhi oleh faktor penguasaan bekal-bekal teoritis dan berbagai hasil latihan dalam kegiatan perkuliahan atau berbagai kegiatan akademik. Bekal akademik mencakup berbagai mata kuliah yang berkaitan dengan bekal pengelolaan, pemahaman perkembangan dan belajar anak, strategi dan perencanaan pembelajaran, materi yang akan diajarkan, pengayaan materi, praktik dalam skala mikro, maupun berbagai observasi dan praktik sebagai implementasi dari berbagai mata kuliah (Susiani, 2007).

Ukuran kinerja guru terlihat dari rasa tanggungjawabnya menjalankan amanah, profesi yang diembannya, serta rasa tanggungjawab moral dipundaknya (Darmadi, 2010:60). Indikator kinerja guru dalam melaksanakan tugas utamanya mengajar adalah: (1) pemahaman tentang strategi pembelajaran; (2) kemahiran dalam mengelola kelas (3) kemampuan melakukan penelitian tindakan kelas; (4) motivasi berprestasi; (5) disiplin; (6) komitmen profesi; (7) kemampuan manajemen waktu (Mulyasa, 2009:9).

IKIP PGRI Madiun, sebagai institusi pendidikan guru tingkat perguruan tinggi, turut memegang peranan dalam mempersiapkan calon guru yang sukses dalam uji kompetensi guru. Oleh karena itu, IKIP PGRI Madiun menyelenggarakan praktik keguruan yang dikemas dalam program Praktik Pengalaman Lapangan (PPL) meliputi: praktik mengajar, praktik administrasi, praktik bimbingan dan konseling, serta kegiatan yang bersifat ekstra kurikuler yang berlaku di sekolah atau tempat latihan.

Penelitian empiris tentang praktik pengalaman lapangan dan kinerja telah menarik perhatian beberapa peneliti dengan mempertimbangkan variabel kompetensi 
guru. Susiani (2007), Bahri (2011) dan Wibowo (2013) membuktikan bahwa motivasi berpengaruh signifikan terhadap kinerja guru. Wibowo (2013) juga menemukan bahwa komunikasi internal berpengaruh signifikan terhadap kinerja guru. Lebih lanjut, Mardiyono (2006) mengungkapkan bahwa faktor pendukung PPL perlu diantisipasi sedemikian rupa sehingga optimalisasi kualitas pelaksanaan PPL dapat terwujud, yaitu: penguasaan kompetensi keilmuan sesuai dengan bidang yang ditekuni dan praktik keterampilan pembelajaran termasuk keterampilan lain pendukung profesionalisme calon guru.

Perbedaan penelitian yang dilakukan sekarang dibandingkan dengan penelitian terdahulu adalah penelitian ini menguji kompetensi yang harus dikuasai dalam melaksanakan Praktik Pengalaman Lapangan yang terdiri dari kompetensi pedagogik, kompetensi profesional, kompetensi sosial, dan kompetensi kepribadian terhadap kinerja mahasiswa calon guru di Program Studi Pendidikan Akuntansi IKIP PGRI Madiun.

\section{METODE}

Populasi penelitian ini adalah seluruh mahasiswa Fakultas Pendidikan Ilmu Pengetahuan Sosial angkatan 2008 dan 2009 yang melaksanakan Praktik Pengalaman Lapangan (PPL) di Kota dan Kabupaten Madiun yang berjumlah 204 mahasiswa. Pengambilan sampel dilakukan dengan teknik purposive sampling, dimana pada masing-masing kelas di tiap angkatan (VIIA, VIIB, VIIC, VIID, dan IX) diambil 30 responden. Total sampel yang digunakan dalam penelitian ini adalah 150 responden.

Data yang digunakan adalah data primer dengan teknik wawancara dan kuesioner. Penelitian ini menggunakan skala likert, yang terdiri dari lima pilihan jawaban atas pernyataan yang diajukan. Dalam hal ini, jawaban selalu diberi skor 5, sering diberi skor 4, kadang-kadang diberi skor 3, jarang diberi skor 2, dan tidak pernah diberi skor 1. Variabel dependen dalam penelitian ini adalah Kinerja (Y). Indikator kinerja guru dalam penelitian ini adalah: (1) motivasi berprestasi; (2) disiplin; dan (3) komitmen profesi (Mulyasa, 2009:9). Sementara itu, variabel independen dalam penelitian ini adalah Praktik Pengalaman Lapangan (X) yang terdiri dari: kompetensi pedagogik, kompetensi profesional, kompetensi sosial, dan kompetensi kepribadian. 
Kompetensi pedagogik mengukur tentang perancangan dan pelaksanaan pembelajaran, pemahaman terhadap peserta didik, serta pelaksanaan evaluasi hasil belajar. Kompetensi profesional mengukur tentang pengembangan Kurikulum Tingkat Satuan Pendidikan, penggunaan media dan sumber pembelajaran, jenis materi pembelajaran serta pengelolaan kelas. Kompetensi sosial mengukur tentang komunikasi, pergaulan, dan peran guru di masyarakat. Kompetensi kepribadian mengukur tentang kedisiplinan dan keteladanan bagi peserta didik.

Kerangka konsep dalam penelitian ini menjelaskan bahwa kinerja mahasiswa calon guru dipengaruhi oleh variabel kompetensi pedagogik, kompetensi profesional, kompetensi social, dan kompetensi kepribadian seperti yang disajikan dalam gambar berikut ini:

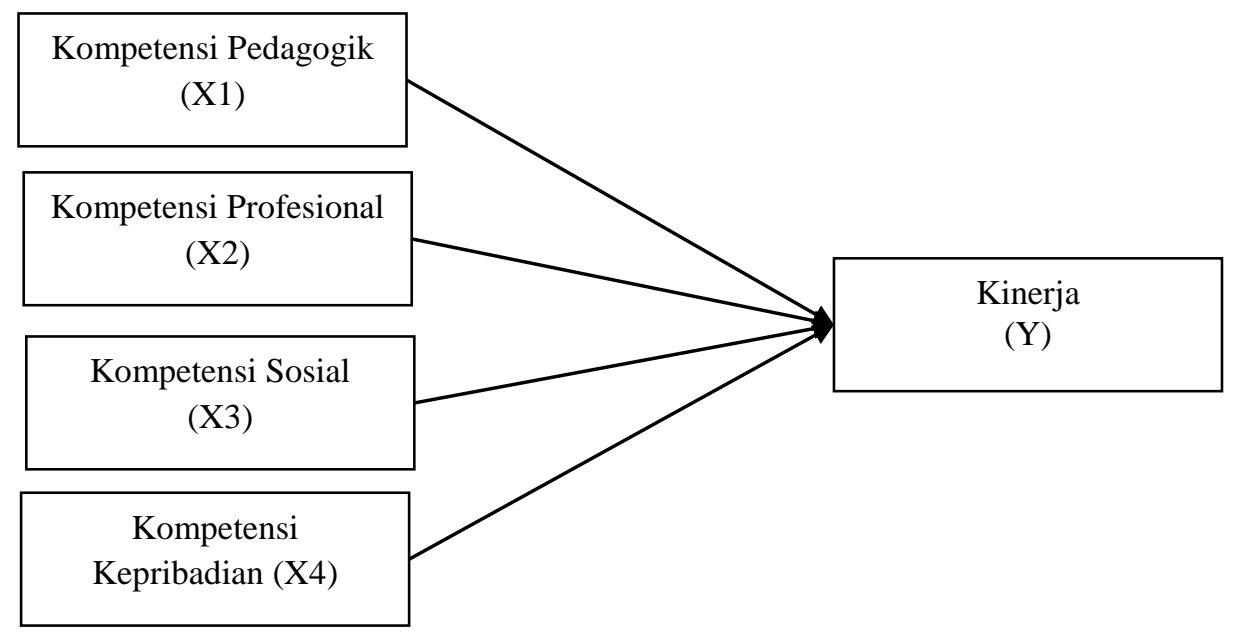

\section{Gambar 1 : Kerangka Konsep}

Berdasarkan kerangka konsep penelitian, hipotesis penelitian yang diajukan sebagai berikut:

$\mathrm{H}_{1} \quad$ : kompetensi pedagogik berpengaruh terhadap kinerja mahasiswa calon guru

$\mathrm{H}_{2} \quad$ : kompetensi profesional berpengaruh terhadap kinerja mahasiswa calon guru

$\mathrm{H}_{3} \quad$ : kompetensi sosial berpengaruh terhadap kinerja mahasiswa calon guru

$\mathrm{H}_{4} \quad$ : kompetensi kepribadian berpengaruh terhadap kinerja mahasiswa calon guru 
Model empiris yang digunakan dalam penelitian ini adalah model regresi berganda, dengan alat analisis SPSS versi 20.0. Bentuk dari model regresi berganda dalam penelitian ini adalah:

$Y=\beta_{0}+\beta_{1} X_{1}+\beta_{2} X_{2}+\beta_{3} X_{3}+\beta_{4} X_{4}+\varepsilon$

Keterangan:

$\mathrm{Y}=$ Kinerja

$\beta_{0} \quad=$ Konstanta

$\beta_{1 \ldots . . .} \beta_{4} \quad=$ Koefisien Regresi

$\mathrm{X}_{1} \quad=$ Kompetensi Pedagogik

$\mathrm{X}_{2} \quad=$ Kompetensi Profesional

$\mathrm{X}_{3} \quad=$ Kompetensi Sosial

$\mathrm{X}_{4} \quad=$ Kompetensi Kepribadian

$\varepsilon \quad=$ Error (kesalahan residu)

\section{HASIL DAN PEMBAHASAN}

Hasil

Penelitian ini telah memenuhi uji asumsi klasik. Hasil pengujian hipotesis dapat dilihat pada tabel 1 berikut.

Tabel 1. Hasil Analisis Regresi

\begin{tabular}{|l|c|c|}
\hline \multicolumn{3}{|c|}{ Dependen Variabel : Kinerja (Y) } \\
\hline \multicolumn{1}{|c|}{ Variabel Independen } & Koefisien Regresi & Prob sig \\
\hline Kompetensi Pedagogik $\left(\mathrm{X}_{1}\right)$ & 0.014 & 0.868 \\
\hline Kompetensi Profesional $\left(\mathrm{X}_{2}\right)$ & 0.023 & 0.792 \\
\hline Kompetensi Sosial $\left(\mathrm{X}_{3}\right)$ & 0.203 & $0.021^{*}$ \\
\hline Kompetensi Kepribadian $\left(\mathrm{X}_{4}\right)$ & 0.236 & $0.014^{*}$ \\
\hline Adjusted $\mathrm{R}^{2} \quad: 0.129$ & \\
\hline Konstanta : 1.628 & \\
\hline
\end{tabular}

Sumber: Data penelitian yang diolah, 2012

Berdasarkan tabel di atas, keempat variabel independen yang dimasukkan dalam model ternyata tidak semuanya signifikan, hanya variabel Kompetensi Sosial $\left(\mathrm{X}_{3}\right)$ dan Kompetensi Kepribadian $\left(\mathrm{X}_{4}\right)$ yang signifikan dengan nilai probabilitas masing-masing sebesar 0.021 dan 0.014. Dengan melihat koefisien regresi, persamaan (model) regresi dapat dibuat sebagai berikut: 


$$
\mathrm{Y}=1.628+0.014 \mathrm{X}_{1}+0.023 \mathrm{X}_{2}+0.203 \mathrm{X}_{3}+0.236 \mathrm{X}_{4}
$$

Nilai konstanta sebesar 1.628 menunjukkan bahwa jika tidak ada peningkatan kompetensi pedagogik, kompetensi profesional, kompetensi sosial, dan kompetensi kepribadian, maka kinerja mahasiswa calon guru sebesar 1.628. Koefisien regresi 0.014 menunjukkan bahwa setiap peningkatan satu satuan kompetensi pedagogik akan meningkatkan kinerja mahasiswa calon guru sebesar 0.014 satuan. Koefisien regresi 0.023 menunjukkan bahwa setiap peningkatan satu satuan kompetensi profesional akan meningkatkan kinerja mahasiswa calon guru sebesar 0.023 satuan. Koefisien regresi 0.203 menunjukkan bahwa setiap peningkatan satu satuan kompetensi sosial akan meningkatkan kinerja mahasiswa calon guru sebesar 0.203 satuan. Koefisien regresi 0.236 menunjukkan bahwa setiap peningkatan satu satuan kompetensi kepribadian akan meningkatkan kinerja mahasiswa calon guru sebesar 0.236 satuan.

\section{Pembahasan}

\section{Pengaruh Kompetensi Pedagogik Terhadap Kinerja Mahasiswa Calon Guru}

Berdasarkan tabel 1 dapat disimpulkan bahwa hasil pengujian H1 ditolak. Kompetensi pedagodik yang dijalankan seharusnya memberikan dorongan bagi mahasiswa calon guru untuk meningkatkan kinerjanya. Akan tetapi, kompetensi pedagogik yang berkaitan dengan penyusunan perencanaan dan pengevaluasian pembelajaran hanya dilaksanakan sebatas kelengkapan saja tanpa adanya pemahaman sehingga mahasiswa calon guru merasa enggan untuk meningkatkan kinerjanya. Menurut Dewanti (2012), mahasiswa sudah mampu menyusun RPP yang sesuai dengan ketentuan kelengkapan RPP, kesesuaian perumusan tujuan pembelajaran dengan standar kompetensi, kompetensi dasar, dan indikator pencapaian kompetensi, serta kesesuaian materi pokok dan uraiannya dengan silabus. Namun, sebagian besar mahasiswa kurang memperinci langkah-langkah pembelajaran sehingga pada praktiknya mahasiswa masih sering kelabakan ketika harus menyiapkan apersepsi secara mendadak.

\section{Pengaruh Kompetensi Profesional Terhadap Kinerja Mahasiswa Calon Guru}

Berdasarkan tabel 1 dapat disimpulkan bahwa hasil pengujian $\mathrm{H} 2$ ditolak. Kompetensi profesional yang dijalankan seharusnya memberikan dorongan bagi mahasiswa calon 
guru untuk meningkatkan kinerjanya. Hal ini disebabkan dalam pelaksanaan PPL, mahasiswa calon guru kurang menguasai bahan ajar yang berkenaan dengan pengetahuan ilmu akuntansi sehingga kinerjanya tidak dapat ditingkatkan.

\section{Pengaruh Kompetensi Sosial Terhadap Kinerja Mahasiswa Calon Guru}

Berdasarkan tabel 1 dapat disimpulkan bahwa hasil pengujian $\mathrm{H} 3$ diterima. Hal ini menunjukkan bahwa mahasiswa IKIP PGRI dalam melaksanakan PPL mudah bergaul dengan para guru, karyawan, dan siswa sehingga dapat mendorong kinerjanya. Hasil penelitian ini sejalan dengan penelitian Bahri (2011) dan Wibowo (2013) yang menemukan bahwa kompetensi sosial yang terdiri dari komunikasi dan lingkungan kerja berpengaruh positif terhadap kinerja guru. Komunikasi, baik yang bersifat vertikal, horisontal, diagonal, formal, informal dan nonformal dapat meningkatkan kemampuan guru dalam pengelolaan proses belajar mengajar, pembaruan dalam proses belajar, sikap objektif guru dalam memberikan penilaian terhadap siswa, komunikasi dengan siswa, serta sikap empatik dan kerja sama dengan rekan kerja dalam sekolah.

\section{Pengaruh Kompetensi Kepribadian Terhadap Kinerja Mahasiswa Calon Guru}

Berdasarkan tabel 1 dapat disimpulkan bahwa hasil pengujian H4 diterima. Mahasiswa IKIP PGRI dalam melaksanakan PPL secara umum menampilkan diri sebagai pribadi yang dewasa, arif, berwibawa, jujur, berakhlak mulia, serta bertindak sesuai dengan norma yang berlaku sehingga dapat mendorong kinerjanya. Hasil penelitian ini sejalan dengan hasil penelitian Susiani (2007), Bahri (2011), Wardoyo (2011) dan Wibowo (2013) yang menyimpulkan bahwa kompetensi kepribadian berpengaruh signifikan terhadap kinerja guru. Menurut Susiani (2007), kinerja guru tidak cukup hanya menguasai berbagai teori, praktik, dan berbagai keterampilan, tetapi terdapat unsur internal inidividu yang berpengaruh, antara lain: sikap, rasa mencintai tugas, dan motivasi diri. Wibowo (2013) menambahkan, motivasi merupakan dorongan yang kuat dan timbul pada diri seseorang secara sadar ataupun tidak sadar untuk melakukan suatu tindakan dengan tujuan tertentu agar terhindar dari kegagalan.

\section{SIMPULAN DAN SARAN}


Berdasarkan hasil penelitian, dapat disimpulkan bahwa kompetensi sosial dan kompetensi kepribadian berpengaruh positif dan signifikan terhadap kinerja mahasiswa calon guru Program Studi Pendidikan Akuntansi IKIP PGRI Madiun dalam melaksanakan Praktik Pengalaman Lapangan. Hal ini membuktikan bahwa mahasiswa Program Studi Pendidikan Akuntansi IKIP PGRI Madiun dalam melaksanakan Praktik Pengalaman Lapangan mudah bergaul dengan para guru, karyawan, dan siswa serta mampu menampilkan diri sebagai pribadi yang dewasa, arif, berwibawa, jujur, berakhlak mulia, serta bertindak sesuai dengan norma yang berlaku. Sebaliknya, kompetensi pedagogik dan kompetensi profesional tidak berpengaruh signifikan terhadap kinerja mahasiswa calon guru. Hal ini dikarenakan mahasiswa dalam pelaksanaan Praktik Pengalaman Lapangan kurang mempersiapkan langkah-langkah pembelajaran serta bahan ajar sehingga mahasiswa tidak bisa mengatasi kelas dengan baik.

Hasil penelitian ini diharapkan dapat dijadikan bahan pemikiran Lembaga Pendidikan dan Tenaga Kependidikan (LPTK) sebagai upaya membangun serta mengembangkan kemampuan mahasiswa calon guru dalam hal ini kompetensi sor dan kepribadian demi mewujudkan pendidikan yang berkualitas.

\section{DAFTAR PUSTAKA}

Bahri, Syamsul. 2011. Faktor Yang Mempengaruhi Kinerja Guru Sd di Dataran Tinggimoncong Kabupaten Gowa Provinsi Sulawesi Selatan. Jurnal MEDTEK, Volume 3, Nomor 2.

Barizi, Ahmad dan Muhammad Idris. 2010. Menjadi Guru Unggul. Jogjakarta: Ar-Ruzz Media.

Darmadi, Hamid. 2010. Kemampuan Dasar Mengajar. Bandung: Alfabeta.

Dewanti, Sintha Sih. 2012. Analisis Kesiapan Mahasiswa Program Studi Pendidikan Matematika Sebagai Calon Pendidik Profesional. Seminar Nasional Pendidikan Matematika Surakarta.

Ghozali, Imam. 2006. Aplikasi Analisis Multivariate Dengan Program SPSS. Cetakan IV. Badan Penerbit Universitas Diponegoro Semarang.

Hamalik, Oemar. 2004. Pendidikan Guru Berdasarkan Pendekatan Kompetensi. Jakarta: Bumi Aksara. 
Mardiyono, Sugeng. 2006. Praktik Pengalaman Lapangan Terpadu Dalam Peningkatan Kualitas Calon Guru. Cakrawala Pendidikan. Februari.

Mulyasa, E. 2009. Standar Kompetensi dan Sertifikasi Guru. Bandung: Remaja Rosdakarya.

Peraturan Pemerintah Republik Indonesia Nomor 19 Tahun 2005 tentang Standar Nasional Pendidikan.

Susiani, Tri Saptuti. 2007. Kinerja Calon Guru Sekolah Dasar. Inovasi Pendidikan, Jilid 8, No. 2.

Wibowo, Bambang Kristianto. 2013. Pengaruh Komunikasi Internal, Motivasi Kerja, Dan Loyalitas Terhadap Kinerja Guru Sekolah Menengah Kejuruan Negeri Rumpun Bisnis Sekota Semarang. Jurnal Stie Semarang, Vol 5, No 2. 